\title{
Climate change impacts on glacier-fed and non-glacier-fed ecosystems of the Indian Himalayan Region: people's perception and adaptive strategies
}

\author{
Jagdish Chandra Kuniyal ${ }^{1, *}$, Nidhi Kanwar ${ }^{1}$, Ajay Singh Bhoj ${ }^{1}$, \\ Kuldeep Singh Rautela ${ }^{1}$, Pramod Joshi $^{1}$, Kireet Kumar ${ }^{1}$, Mohd Sharjeel Sofi ${ }^{2}$, \\ Sami Ullah Bhat ${ }^{2}$, Irfan Rashid ${ }^{3}$, Mahindra Singh Lodhi ${ }^{4}$, Ch. Anniebesant Devi ${ }^{5}$ \\ and Huidrom Birkumar Singh ${ }^{5}$
}

\author{
${ }^{1}$ Govind Ballabh Pant National Institute of Himalayan Environment, Kosi-Katarmal, Almora 263 643, India \\ ${ }^{2}$ Department of Environmental Science, School of Earth and Environmental Sciences, University of Kashmir, Srinagar 190006 , India \\ ${ }^{3}$ Department of Botany, University of Kashmir, Srinagar 190 006, India \\ ${ }^{4}$ Govind Ballabh Pant National Institute of Himalayan Environment, North-East Regional Centre, Itanagar 791 113, India \\ ${ }^{5}$ CSIR: North-East Institute of Science and Technology, Branch Laboratory, Lamphelpat, Imphal 795 004, India
}

\begin{abstract}
Mountains are considered as the early indicators of climate change. The study aims to understand how the Himalayan communities perceive climate change, and how this change has impacted the livelihood and sustenance of local people particularly in the remote and rural areas of the region. In view of this, 994 households of 25 villages were interviewed from five basins (five villages per basin) of the Indian Himalayan Region. Their perceptions mainly of climate change were validated/compared with the available climatic indices. People perceived rainfall pattern to be less predictable, greater change in land-use pattern, adverse impacts on forests and human health and overall reduction in their harvests. Seasonal increase in temperature was also reported. Capacity-building programmes for the inhabitants, including the most vulnerable communities in the wake of climate change would be significantly fruitful by way of mitigation and adaptation strategies.
\end{abstract}

Keywords: Adaptive strategies, climate change, glacierfed and non-glacier-fed ecosystems, people's perception.

\section{Introduction}

CLIMATE change is a major challenge being faced by the world mountains, including the Himalayan region which shows a clear-cut indication in many areas ${ }^{1}$. It is considered as a significant threat to rural communities that are more dependent on natural resources. Especially in developing countries, the impacts are more severe, but those residing in high-risk regions in developed countries are also

\footnotetext{
*For correspondence. (e-mail: jckuniyal@gmail.com)
}

greatly impacted ${ }^{2,3}$. For developing nations such as India, where agriculture continues to be the backbone to support livelihood options for more than two-thirds of the population, a study of the nature and impact of climate change on agriculture and people's livelihood is of greater importance ${ }^{4}$. Changes in temperature and precipitation patterns and their impacts on water resources, glaciers, ecology, agriculture, etc. are being attributed to changing climate over the Himalaya ${ }^{5,6}$. Temperature is showing an increasing trend in the Western Himalaya, while precipitation is showing a decreasing trend during winter and summer periods $^{7-9}$. Receding of glaciers and upward movement of snowlines affect river-water discharge and volume in the downslope region. This change in water flow may lead to a variety of social issues, and would adversely affect hydropower energy generation, existing biodiversity and agriculture-based livelihood options ${ }^{1}$.

For centuries indigenous communities have witnessed local changes in climatic conditions in their surroundings. They have a rich experience with their ecosystem's natural rhythms and processes ${ }^{10}$. Concurrence between scientifically documented facts and local observations exists in the Himalayas ${ }^{11-13}$. Communities whose livelihoods and lives rely on natural resources and ecosystem services are often the first to perceive changes. There has been indigenous knowledge about such changes since many back decades and has been documented in many of the Himalayan studies ${ }^{12-14}$ and studies from other similar regions of the world ${ }^{15,16}$.

Several studies evaluating the impact of climate change on forest ecosystems ${ }^{17,18}$, socio-economic conditions and human health ${ }^{19-22}$ and land-use pattern ${ }^{23-25}$ in India are available. However, the present study deals with climate change-driven livelihood practices from changing land 


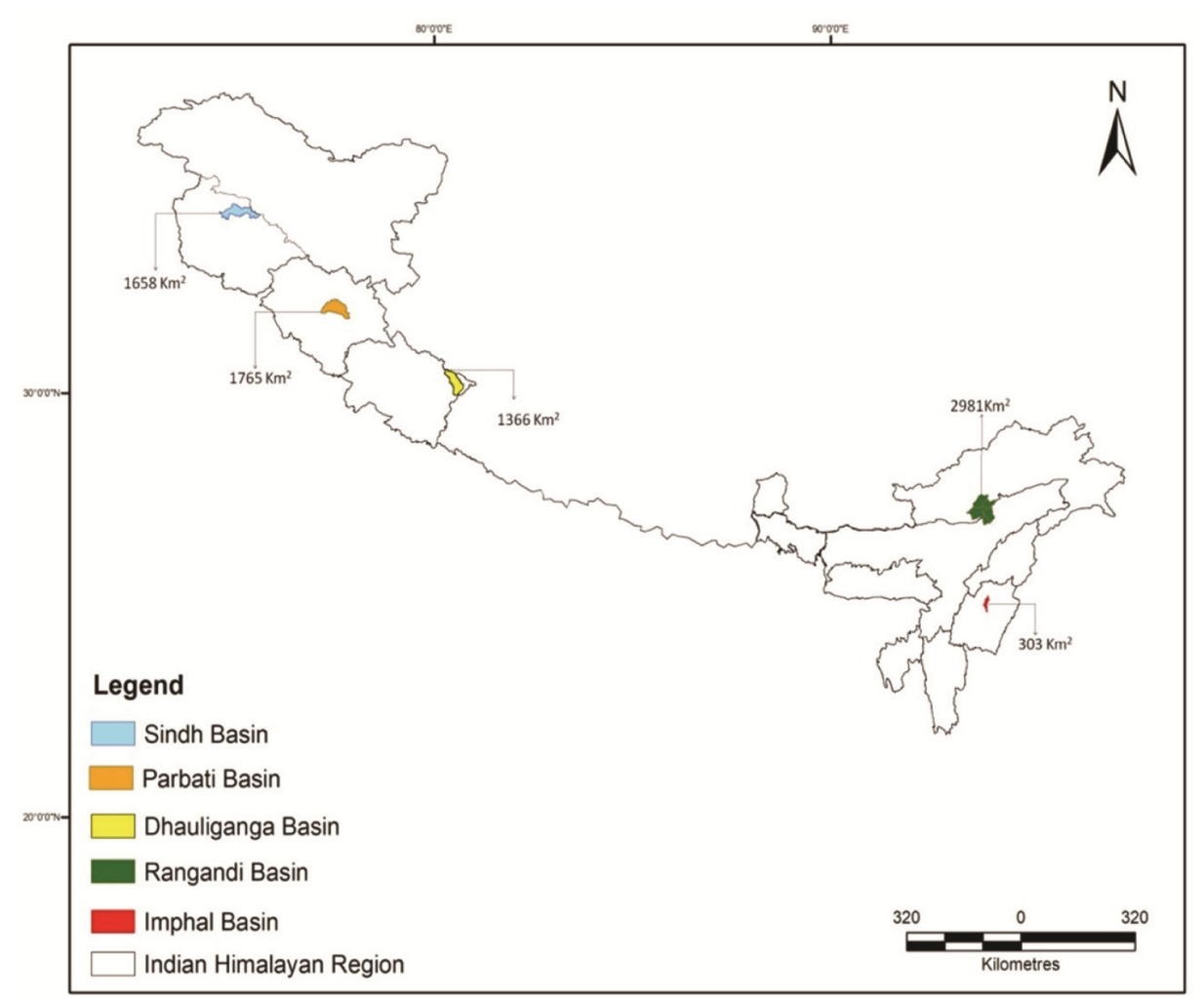

Figure 1. Study locations in the Indian Himalayan Region.

use and developmental interventions in terms of a comparison between glacier-fed and non-glacier-fed basins in the northwestern to northeastern regions respectively, of the Indian Himalayan Region (IHR). The objectives of the present study were to: identify people's perceptions on climate variability, understand how people's livelihoods and socio-economic conditions are being affected due to climate change, and to assess how vulnerability, and adaptive capacity vary among different communities along with possible adaptative strategies.

\section{Study area}

The present study area includes five different basins across the IHR: (i) Sindh Basin $\left(1683 \mathrm{~km}^{2}\right)$, Jammu and Kashmir; (ii) Parbati Basin $\left(1765 \mathrm{~km}^{2}\right)$, Himachal Pradesh; (iii) Dhauliganga Basin $\left(1366 \mathrm{~km}^{2}\right)$, Uttarakhand; (iv) Ranganadi Basin $\left(2981 \mathrm{~km}^{2}\right)$, Arunachal Pradesh, and (v) Imphal Basin (303 km²), Manipur (Figure 1).

\section{Methodology}

An in-depth household survey using a common, wellstructured questionnaire for all the sites was undertaken in the selected villages of the five basins of the IHR from 2017 to 2018. Exercises such as individual direct interviews and common group discussions were conducted using a semi-structured questionnaire to obtain people's perceptions regarding impacts of climate change in their areas. The survey was conducted in Hindi and/or local languages for better understanding of the respondents. An overview of the questions framed includes: how changes are taking place in climatic conditions over the years, how climate change is affecting common people's lives, decreasing volume of water bodies and increasing water demand of the people, changing land-use pattern, shift in the vegetation cover and health issues involving increase in flies and mosquitoes, etc.

Overall, 25 villages (five villages per basin) having 994 households were surveyed. The villages from high to low altitude in the Sindh Basin were: Nilgrad (2296 m), Gagangir (2275 m), Drag Tanga (2193), Wail (2188 m), and Preng $(1731 \mathrm{~m})$. Villages in the Parbati Basin taken under study were: Nakthan (2672 m), Ucch (2324 m), Tahuk $(2287 \mathrm{~m})$ and Shila $(2258 \mathrm{~m})$, and Bershaini $(2205 \mathrm{~m})$. In the Dhauliganga Basin the villages under survey were: Dar $(2175 \mathrm{~m})$, Btan $(2145 \mathrm{~m})$, Tejan (1965 m), Gargwa (1714 m) and Sobla (1594 m). The non-glacier-fed villages, Possa $(845 \mathrm{~m})$, Peni $(631 \mathrm{~m})$, Chulung $(648 \mathrm{~m})$, Yazali C-sector $(616 \mathrm{~m})$ and Thowu $(564 \mathrm{~m})$ were surveyed in the Ranganadi Basin. Five villages, viz. North $(1075 \mathrm{~m})$ and South Sapermeina (1049 m), Awang Sekmai (829 m), Motbung (914 m) and Kanglatongbi Mandir (869 m) of the Imphal Basin were surveyed. 
Random sampling was adopted covering $>30 \%$ of the total households in the 25 villages under study. The respondents had spent most of their lifetimes in their respective communities. The age of the interviewees ranged from 25 to 80 years. Special care was taken to select elderly people for the survey, as they are well-experienced. Within each household, mostly the head of the family was interviewed. Along with the family heads, women of the family were also interviewed to represent gender. In view of maintaining gender balance, $50 \%$ of those surveyed included women. In addition, youth were also interviewed who had some modern ideas and also could represent new generation.

Daily Climate Forecast System Reanalysis (CFSR) data in terms of different parameters (maximum and minimum temperatures and precipitation) were downloaded and used to study seasonal climatic variations having $38 \mathrm{~km}$ horizontal resolution. Climatic data of the past 35 years (1979-2014) for daily maximum and minimum temperatures and precipitation analysis were used. These data were grouped to represent summer (May to September) and winter (November to April) seasons for glacierfed region. While non-glacier-fed region represented summer from May to October and winter from November to April $^{26-28}$. The rate of increase/decrease of seasonal climatic indices was computed using linear regression slope method. According to this method, the rate of increase/decrease is equal to slope $(b)$ of the regression line multiplied by the total number of years of data records. To explain the significance of the observed data, the trends were subjected to one-tailed Student's $t$-test at 95\% confidence level.

Furthermore, the data collected from questionnaire survey were analysed using chi-square test applied in XLSAT. This was used to test significant differences between responses ${ }^{29}$. The following formula was used

$$
\chi^{2}=\sum \frac{(O-E)^{2}}{E}
$$

where $O$ is the observed frequency and $E$ is the expected frequency in each category.

Regarding adaptive strategies in the wake of climate change threats, a chain of four consultative meetings/ capacity-building programmes were conducted in all the five basins under study.

\section{Results and discussion}

\section{Climate change and its impacts}

The study explains that most of the respondents $(91 \%)$ have experienced significant changes $(P<0.05)$ in the glacier-fed basins, particularly in case of Sindh, Parbati glacier-fed basins and Ranganadi non-glacier-fed basin (Annexure 1). However, in view of changing climate; no such consistency $(P>0.05)$ by $86 \%$ respondents was found in other two basins (Dhauliganga glacier-fed and Imphal basin non-glacier-fed). The interviewees were of the view that glaciers in their respective regions are melting fast due to climate change. Similar views were also expressed by other scholars in the recent past. For example, Koul et al. ${ }^{30}$ studied the Machoi glacier (a source to River Sindh), wherein equilibrium-line altitude (ELA) was shifted from $4540 \mathrm{~m}$ amsl in 2011-12 to $4509 \mathrm{~m}$ amsl in 2013-14 and the glacier snout advanced $4 \mathrm{~m}$ in the central part $(3656-3652 \mathrm{~m})$ but either of its side retreated by $0.56 \mathrm{~m}$. Kulkarni et al. ${ }^{31}$ studied the Parbati glacier which retreated $578 \mathrm{~m}$ between 1990 and 2001 , indicating almost by $52 \mathrm{~m} / \mathrm{yr}$ recede. In another recent study of the Parbati glacier, Kuniyal and Samant ${ }^{32}$ found that its snout had retreated at an average rate of $0.36 \mathrm{~m} / \mathrm{yr}$ from 1962 to 2016 . The overall recession in snow area of the Parbati glacier from 1962 to 2016 was $1228 \pm 93.11 \mathrm{~m}^{2}$, indicating recession at the rate of $0.24 \mathrm{~m}^{2} / \mathrm{yr}$. Similarly, Singh et al. $^{33}$ found that nearby glaciers in the Dhauliganga Basin from 1963 to 2016 reduced by approximately $35 \mathrm{~km}^{2}$.

Table 1 provides summary and statistical significance of the rate of increase/decrease of climatic parameters (temperature and precipitation) during winter $\left(W_{\text {avg }}\right)$ and summer $\left(S U_{\text {avg }}\right)$ respectively ${ }^{25}$. Figures $2 a-c$ and $3 a, b$ show their graphical representation, while Figure $4 a-c$ shows plots of temporal variation of temperature and precipitation with linear trends. The analysis reveals that the seasonal average temperature shows an increasing trend with different rates in different basins under study, except precipitation trend in winter. In the Sindh Basin, 89\% respondents perceived increase in summer temperature, while $79 \%$ of the total respondents perceived increase in winter temperature. The results of climatic parameters reveal that in the Sindh Basin, maximum $\left(0.011^{\circ} \mathrm{C} / \mathrm{yr}\right.$ in summer and $0.227^{\circ} \mathrm{C} / \mathrm{yr}$ in winter $)$, minimum $\left(0.01^{\circ} \mathrm{C} / \mathrm{yr}\right.$ in summer and $0.117^{\circ} \mathrm{C} / \mathrm{yr}$ in winter) average temperatures have shown high rates of increasing trend, which is statistically significant in winter season except a decreasing trend of precipitation $(-0.635 \mathrm{~mm})$ during 1979-2014 (Table 1 and Figures $2 a$ and 4). In the Parbati Basin, 94$97 \%$ of the total respondents perceived significant $(P<0.05)$ changes in precipitation (snowfall and rainfall) amount and pattern, whereas $91 \%$ and $71 \%$ of the total interviewees perceived an increase in summer and winter temperature respectively. The significance test (Student's $t$-test at $95 \%$ confidence level) in the Parbati Basin shows that the trends of average maximum $\left(0.15^{\circ} \mathrm{C} / \mathrm{yr}\right)$ and minimum $\left(0.141^{\circ} \mathrm{C} / \mathrm{yr}\right)$ temperatures in summer and average maximum $\left(0.166^{\circ} \mathrm{C} / \mathrm{yr}\right)$, and minimum $\left(0.158^{\circ} \mathrm{C} / \mathrm{yr}\right)$ temperatures in winter are statistically significant, except precipitation $(-2.233 \mathrm{~mm}$ in summer and $-1.17 \mathrm{~mm}$ in winter) indicating a seasonal decreasing trend (Table 1 
Table 1. Rate of increase/decrease of seasonal average maximum and minimum temperatures $\left({ }^{\circ} \mathrm{C}\right)$ and precipitation (mm) in the Indian Himalayan Region

\begin{tabular}{|c|c|c|c|c|c|c|}
\hline \multirow[b]{2}{*}{ Basin } & & \multicolumn{3}{|c|}{ Glacier-fed } & \multicolumn{2}{|c|}{ Non-glacier-fed } \\
\hline & & Sindh & Parbati & Dhauliganga & Ranganadi & Imphal \\
\hline \multirow[t]{3}{*}{ Summer } & Maximum temperature & 0.011 & 0.15 & 0.064 & 0.005 & 0.011 \\
\hline & Minimum temperature & 0.01 & $0.141 *$ & $0.08 *$ & $0.038 *$ & 0.014 \\
\hline & Precipitation & $4.632 *$ & -2.233 & 0.45 & 7.29 & 0.789 \\
\hline \multirow[t]{3}{*}{ Winter } & Maximum temperature & $0.227 *$ & $0.166^{*}$ & $0.047 *$ & $0.172 *$ & $0.065 *$ \\
\hline & Minimum temperature & $0.117 *$ & $0.158 *$ & 0.033 & $0.115^{*}$ & 0.017 \\
\hline & Precipitation & -0.635 & -1.17 & -1.491 & -2.775 & -0.312 \\
\hline
\end{tabular}

*Indicates trend statistical significance at 95\% confidence level (+ for increasing and - for decreasing).
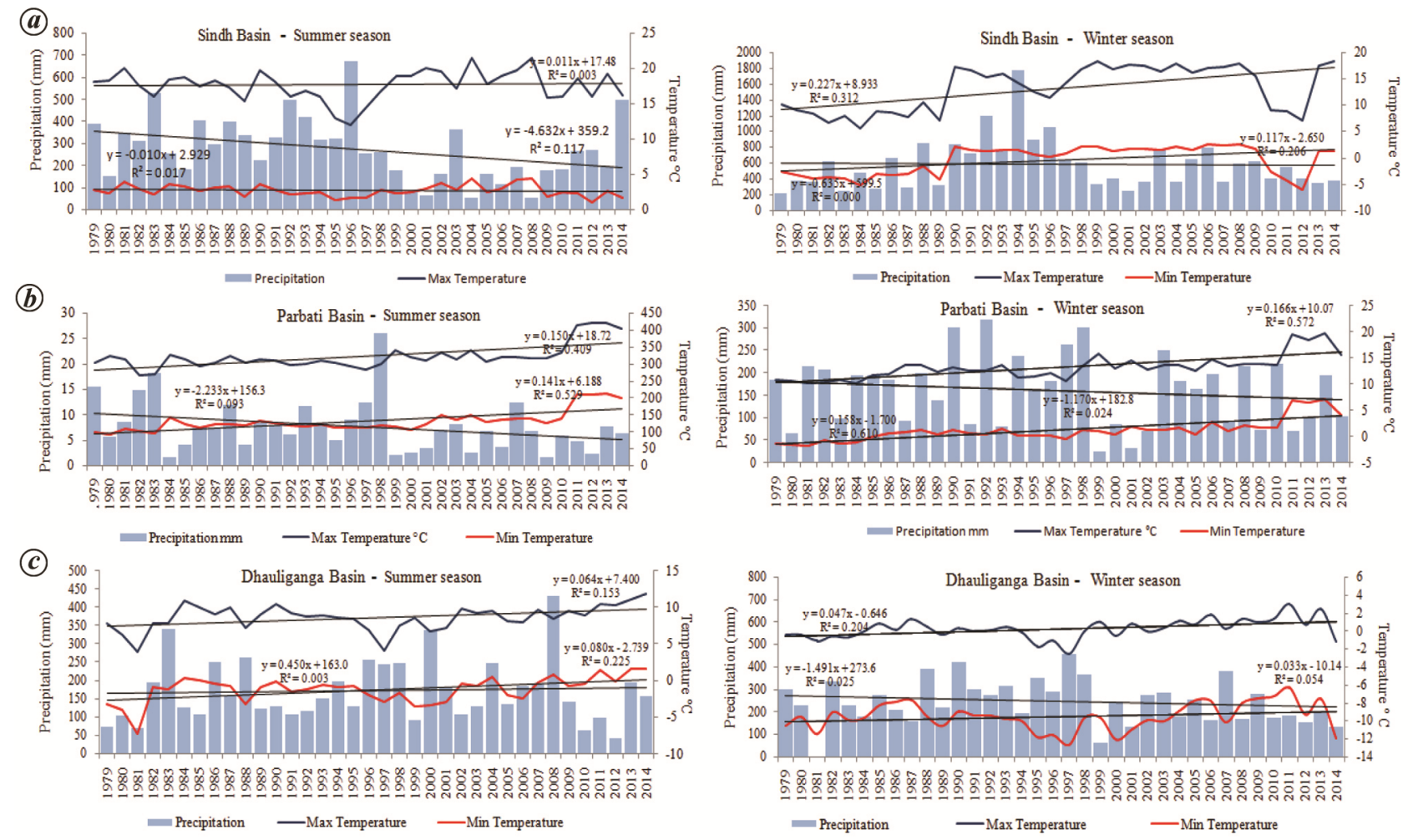

Figure 2. Trends in the seasonal average maximum and minimum temperatures $\left({ }^{\circ} \mathrm{C}\right)$ and precipitation (mm) in the glacier-fed regions: $\boldsymbol{a}$, Sindh Basin; $\boldsymbol{b}$, Parbati Basin; $\boldsymbol{c}$, Dhauliganga Basin.

and Figures $2 b$ and 4 ). About $91 \%$ of the total respondents showed significant difference $(P<0.05)$ in the Dhauliganga Basin; they had observed a change in summer temperature along with increasing trend in winter temperature. The significance test shows that the trend of average maximum $\left(0.064^{\circ} \mathrm{C} / \mathrm{yr}\right)$ and minimum $\left(0.08^{\circ} \mathrm{C} / \mathrm{yr}\right)$ temperatures in summer and average maximum $\left(0.047^{\circ} \mathrm{C} / \mathrm{yr}\right)$ temperature in winter is significantly increasing, except precipitation $(-1.491 \mathrm{~mm}$ in winter) which showed a seasonal decreasing trend from 1979 to 2014. In non-glacier-fed regions, maximum and minimum temperatures in both the seasons showed increasing trend, except precipitation (Table 1 and Figures 3 and 4). Climatic parameters also indicate changing climatic conditions as perceived by people in the IHR. Besides, about
$61 \%$ of the total respondents showed significant difference $(P<0.05)$ in response to alteration in water bodies and $95 \%$ of the total respondents noticed a change in land-use pattern in the Dhauliganga Basin. The present information collected is in line with earlier studies conducted in $\mathrm{IHR}^{34,35}$. The chi-square test also showed significant $(P<0.05)$ differences in different responses obtained from the respondents. These are mainly cropping pattern $(87 \%)$ and land-use pattern $(80 \%)$. Major drivers of climate change were traced in terms of temperature, rainfall and snowfall, and infestation of pests and diseases (Annexure 1). This finding is consistent with other studies highlighting negative consequences of climate change affecting crop yield and food supply in the region $^{36}$. Besides, climate change has started to affect 

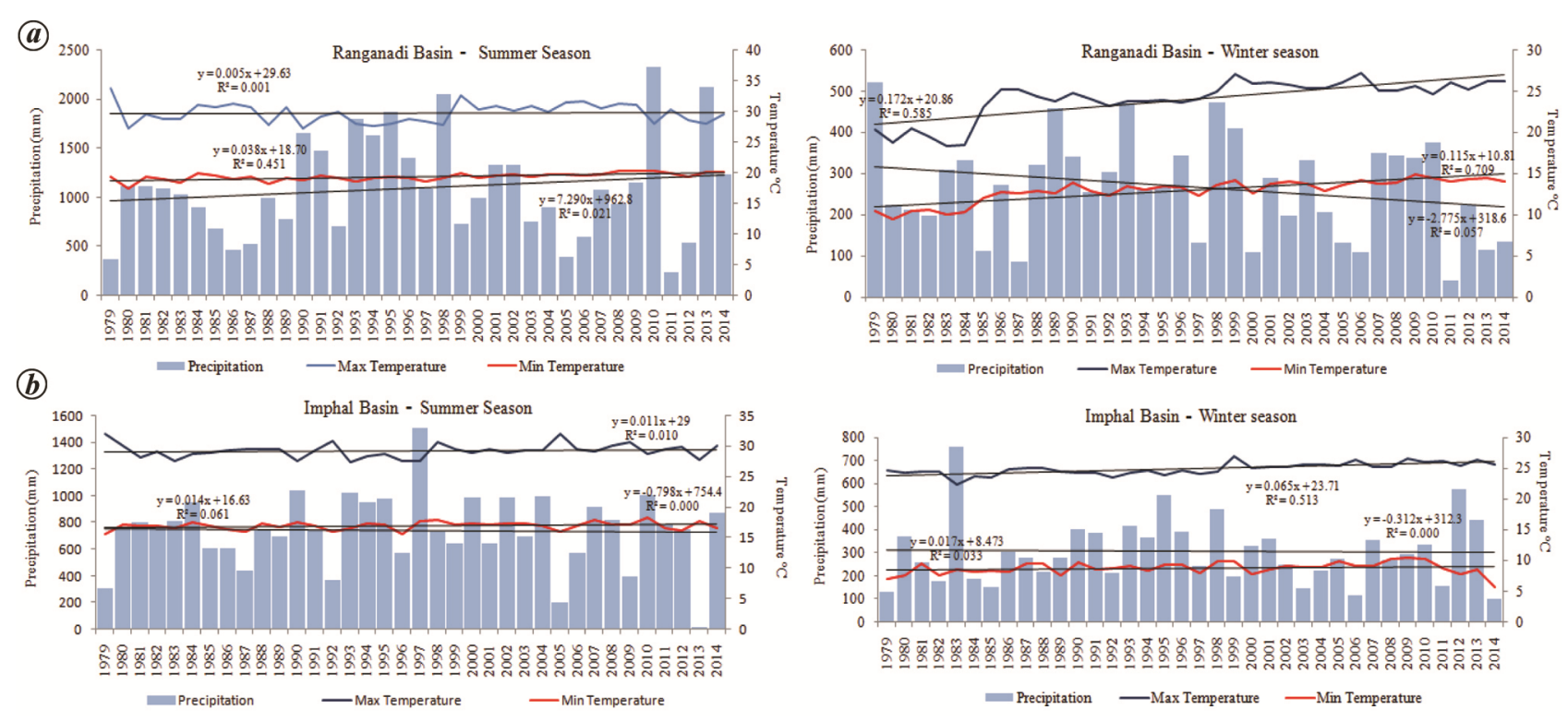

Figure 3. Trends in the seasonal average maximum and minimum temperatures $\left({ }^{\circ} \mathrm{C}\right)$ and precipitation (mm) in the non-glacier-fed regions: $\boldsymbol{a}$, Ranganadi Basin; $\boldsymbol{b}$, Imphal Basin.
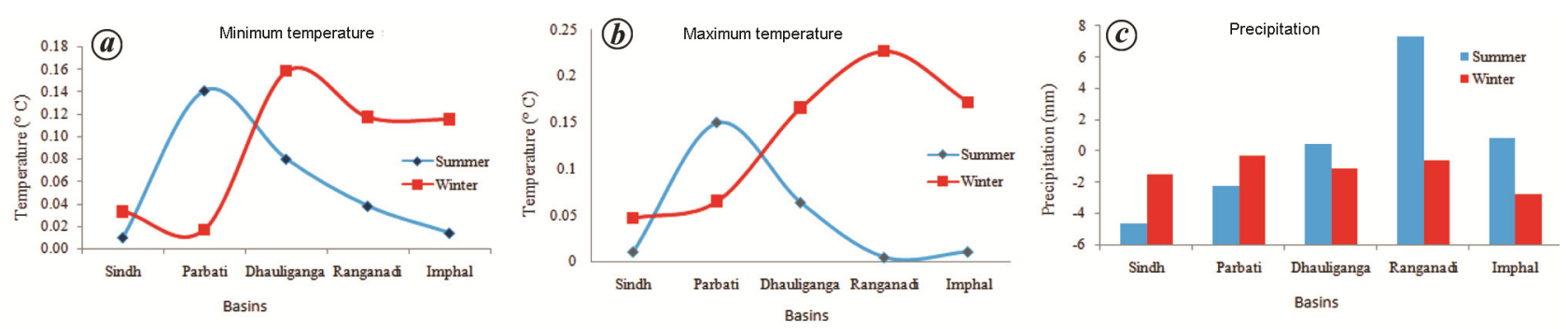

Figure 4. Rate of increase/decrease of seasonal average: $\boldsymbol{a}, \boldsymbol{b}$, Maximum and minimum temperatures $\left({ }^{\circ} \mathrm{C}\right)$; $\boldsymbol{c}$, precipitation $(\mathrm{mm})$ in the glacier-fed and non-glacier-fed regions.

animal and plant physiology, distribution pattern, pheno$\operatorname{logy}$ and inter-specific interactions ${ }^{37,38}$. Thomas et al. ${ }^{39}$ predicted extinction of $15-37 \%$ of the total species due to anthropogenic activity which account for $20 \%$ of the terrestrial surface. With the vulnerability scale being high in the region, a significant change in the climate drivers is marked with magnified consequences in terms of habitat loss, colonization of native habitats by aggressive native colonizers and invasive species. Other than this, changes are reflected as altered phenological events, upward species migration and shifting of tree lines ${ }^{40,41}$.

\section{Impacts on land-use pattern}

Change in existing land-use pattern in terms of forest cover was highest in the non-glacier-fed regions, i.e. Ranganadi Basin (66\%) followed by glacier-fed regions, i.e. Sindh Basin (41\%), although it was least for the Dhauliganga Basin (11\%; Figure $5 a-e)$. In case of per cent change in arable land, its share was highest in Dhauliganga Basin (87\%), followed by Parbati Basin (74\%) and was minimum in the Ranganadi Basin (7\%). The local people from villages at different altitudes in both the regions mentioned that low rainfall or shift in rainfall pattern had resulted in crop failure, declining yield of food grains and fodder (Table 2), less traditional, horticultural crops cultivation and animal husbandry, but more modern cash crops. The traditional crops will soon be replaced with cash crops like vegetables, peas and potato in higher altitudes (Table 3 ). It was also reported by the respondents that use of chemicals has resulted in decrease in soil moisture which will be affected by its changing amount, pattern and precipitation cycle. Respondents from Parbati and Dhauliganga glacier-fed basins as well as Ranganandi and Imphal non-glacier-fed basins raised the issue of relatively less scientifically planned road construction in a fragile mountain ecosystem. This makes the region more vulnerable to landslides mainly during monsoon season; and continuously contributes to loss of soil fertility (Table 2). Thus, both anthropogenic and climatic factors appear to be responsible for reducing agricultural productivity. A highly nutritious fodder is gradually disappearing from the forests ${ }^{42,43}$. 
Table 2. Changes as observed and perceived due to climate change in the IHR

Indicators

Examples

Change in species composition

Growth in unpalatable species

Decrease in alpine grassland productivity

\section{Change in ecotones}

Loss of habitat

Change in land-use practices increases soil erosion/soil fertility and high mortality of species

Reduction in agrodiversity and change in crops and cropping patterns

Increase in temperature

Change in vegetation

Rapid deforestation

Scarcity of drinking water, leading to a great threat to wild flora and fauna

Decline in vegetable and fruit crops productivity

Reducing chilling hours during winters for fruit yield

Degradation of riverine inland ecosystems and associated aquatic biodiversity

Increase in invasive insects, pathogens and animals
Transformation in the structure of alpine vegetation, i.e. earlier vegetation of Quercus semecarpifolia and Betula utilis now accompanied by species such as Rhododendron campanulatum, Salix spp., Syringia embodia, etc.

Substantial declining in the population of insectivorous plants, Mantisia spp., Ilex spp., etc.

Traditional varieties like paddy, wheat, maize, barley, finger millet, beans, cucurbits and citrus are being replaced by cash crops like potato, pea, etc.

Increase in infestation of pests and outburst of new diseases.

Expansion of invasive species in croplands like Lantana camara, Parthenium odoratum, Eupatorium hysterophorus, etc.

Advancement in flowering cycle of Rhododendron species and members of Rosaceae family (e.g., Pyrus, Prunus spp.).

Cash crops (Phaseolus vulgaris and Solanum tuberosum).

Yield of apple and citrus fruits.

Native fish species like Schzothorax niger, Schizothorax labiatus and Schizothorax plagiostomus have been reduced alarmingly.

Species of order Lepidoptera such as Lymantria obfuscata, infest some of the major dominant tree species (i.e. Quercus leucotrichophora, $Q$. dilatata, Alnus nitida, Salix alba, Falix fragilis and several other popular species), resulting in high mortality rate. Sap sucking insects like aphids such as Tuberolachnus saligus kill its host tree.

Croplands are severely damaged due to the menace created by monkeys (Rhesus macaque), wild boar (Sus scrofa) and other wild animals.
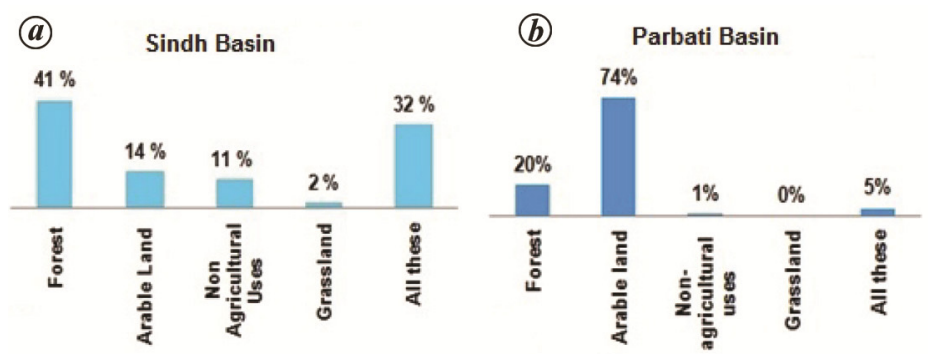

(c) Dhauliganga Basin

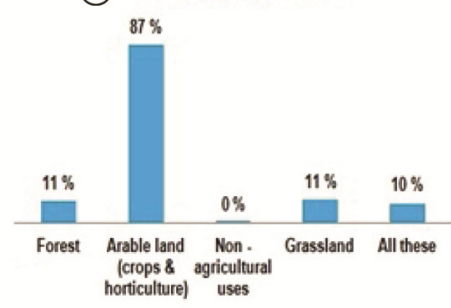

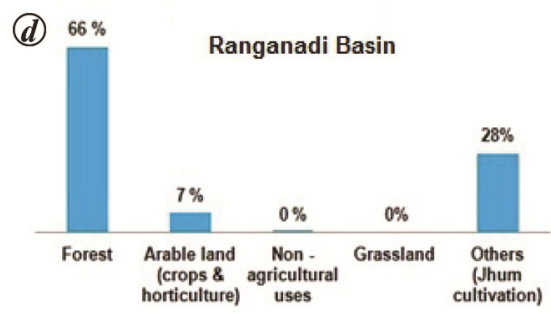

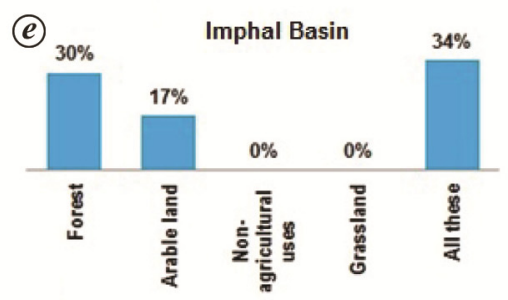

Figure 5. Changing land-use pattern in different basins across the IHR.

\section{Impacts on water resources}

The impact of climate change on the hydrological regime of the Himalayan rivers has been well studied ${ }^{44}$. People's perception survey on snowmelt contribution, water demand and its sources was conducted in the selected basins. About $65 \%$ of the total respondents were of the view that headwater contribution in the Sindh Basin flow due to snow-/glacier-melt water could be between $75 \%$ and $100 \%$ (Figure $6 a$ ). Whereas, $33 \%$ of the total respondents mentioned that $100 \%$ headwater contribution in the Parbati Basin flow is contributed by snow-/glacier-melt 
SPECIAL SECTION:

Table 3. Changes observed due to climatic variability and their adaptation measures in the IHR

\begin{tabular}{lcc}
\hline Climatic variability & Changes observed/perceived by stakeholders & Possible adaptation measures \\
\hline $\begin{array}{c}\text { Temperature rise and } \\
\text { increased precipitation }\end{array}$ & $\begin{array}{c}\text { Decline in snowfall, unpredictable rainy } \\
\text { seasons and their impact on crop sowing }\end{array}$ & $\begin{array}{c}\text { Cultivation of vegetables like peas and } \\
\text { potato at higher altitudes }\end{array}$
\end{tabular}

Long dry spells time

Change in land-use pattern, excessive use of chemical fertilizers to increase soil fertility

Shift in cropping pattern, cultivation practice of cash crops and other varieties relatively with higher yield than age-old traditional varieties with poor yield

Non-glacier-fed regions

Scarcity of water and decline in water quantity in springs and streams, and drying up of natural springs and streams

Changes in the phenology of most fruit and flower plants

Decline in forage and fodder produce and livestock population

Impacts on limited livelihood options of the local communities of rainy season (late September) and low winter precipitation (snowfall) in January and February

Change in forest area

Impact on agriculture
Forest clearance for agriculture, tea cultivation, slash and burn mode of cultivation with ever-reducing 'jhum' cycle, and alteration of prime natural habitat for developmental and industrial activities

Decrease in crop production; crop failure due to unpredictable rainfall, hailstorms, flash flood and infestation of pest and diseases
Establishing a balance between traditional staple crops and cash crops

Focus on rooftop and/or surface run-off rainwater harvesting, rejuvenating and/revival of drying/declining springs, appropriate use of water in the wake of decreasing livestock-rearing in the hills

Establishing a balance between pastureland and livestock populations would be within carrying capacity of an ecosystem. Plant species, category of grazing animals, soil characteristics, micro- and regional climate, etc. need to be assessed thoroughly to value and manage ecosystem Planting fodder trees along the edges of terraced fields and rational use of fodder yield through systemic lopping

Cultivation of higher fodder-yielding varieties with low grain production

Skill development and awareness

Glacier-fed and programmes regarding use of modern tools non-glacier-fed regions and techniques in different sectors like beekeeping, poultry farming, fishing, floriculture, handicrafts, carpentry, ecotourism, medicinal plant cultivation, etc. These alternatives might be potential to sustain local livelihood options

Rejuvenation of the culturable waste, degrading and barren lands through afforestation and reforestation programmes

Glacier-fed and non-glacier-fed regions

Glacier-fed and non-glacier-fed regions

Glacier-fed and non-glacier-fed regions

Glacier-fed and non-glacier-fed regions non-glacier-fed regions

Strengthening irrigation practices, rationale use of high yielding/drought and disease resistant varieties of crops water (Figure $6 b$ ). About $1 \%$ of the total headwater contribution in the River Dhauliganga comes from snow/glacier melt, while maximum respondents (93\%) did not reply to this question (Figure $6 c$ ). The Ranganadi and Imphal basins are non-glacier-fed and here respondents were of the view that snow/glacier had no role in the river flow and rainwater was the only contributor to the same.

In the wake of climate change, rapid snow/glacier-melt accelerates river run-off, which is reported to reduce the ice reserve below a critical threshold. For instance, it re- sults in catastrophic floods that sometimes are referred to as the 'mountain tsunamis', which can deprive people of all means of livelihood in a single stroke ${ }^{45}$. In the glacierfed region in the Sindh Basin, 91\% respondents witnessed alteration in water bodies. Similar results were obtained from non-glacier-fed region in the Imphal Basin, where about $86 \%$ of the total respondents perceived change in volume and drying up of the water bodies. In the Imphal Basin respondents perceived that warmer climate has lead to uncontrolled growth of weeds in the lakes that pollute the water. Increasing floating biomass (phumdi) in 

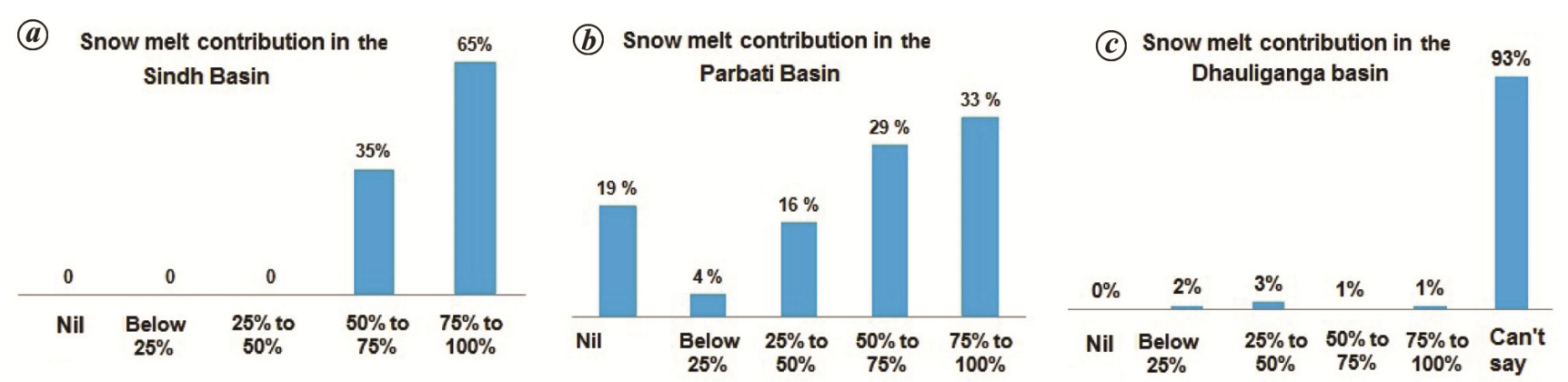

Figure 6. Snowmelt contribution in different river basins.

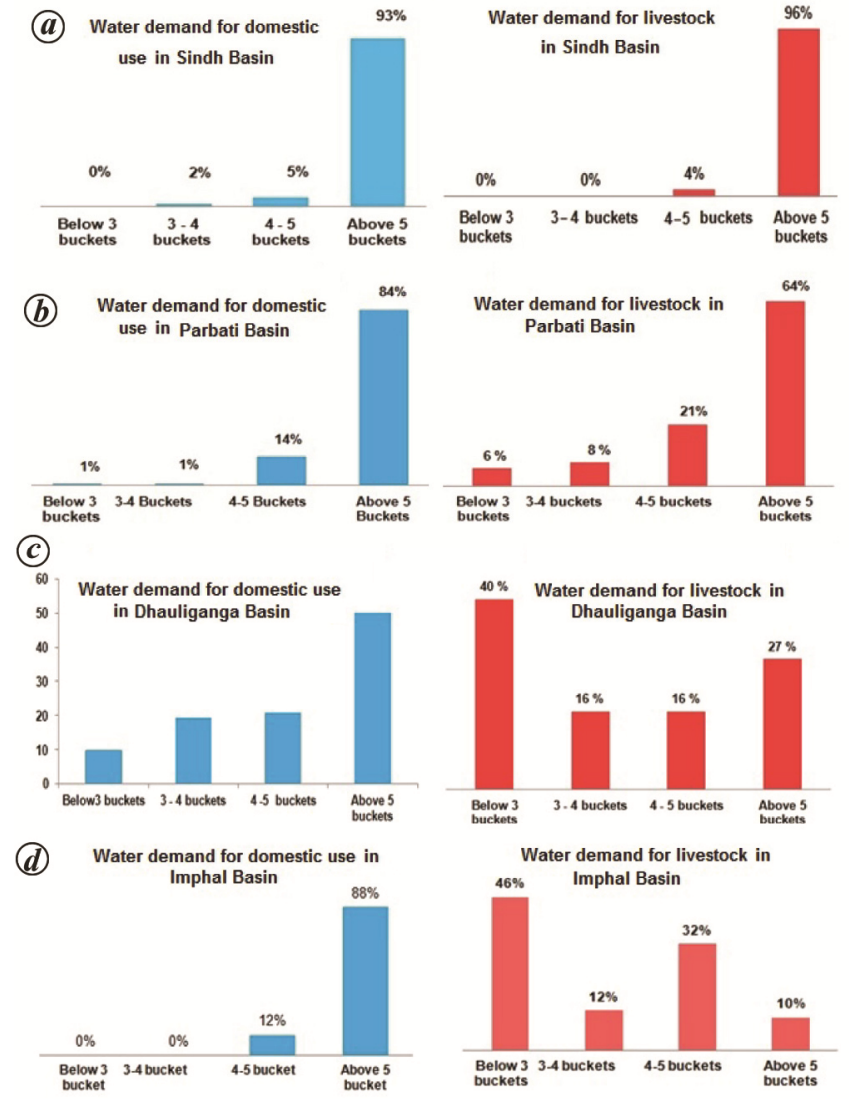

Figure 7. People's perception on water demand for domestic and livestock purposes in the glacier-fed and non-glacier-fed regions.

Loktak Lake may be one of the examples of climate change.

The other responses were on water demand and its usage. On an average, about five buckets of water per day (1 bucket = 151 ), accounting for about $751 /$ day for both domestic as well as livestock population was needed (Figure $7 a-d$ ). The major sources of water are small streams, springs, hand pumps and perennial rivers. The rising temperature will have its impact on the hydrological cycle, as it will cause snowline shift upwards and reduce snow storage capacity of the basin. In the monsoon season, more rainfall contributes to more surface run-off further creating flood conditions, while less run-off in summer season will have an impact on irrigation and hydropower sectors. Some studies have been conducted on global warming and its impact on melting of glaciers in the Himalaya ${ }^{32,46,47}$. In the long-run, this can adversely affect the hydropower projects causing deficit in water supply as raw material and also high debris flow from the moraines and ultimately its deposition in the dams ${ }^{48,49}$. Water quality is important for good health in these highaltitude regions, so there is a need to develop water purification systems in view of maintaining its quality at both individual and community levels.

\section{Impact on forests}

Change in forest ecosystem and its composition is vividly reported by the respondents in glacier-fed regions like the Sindh Basin, wherein about $85 \%$ of the respondents reported a shift in vegetation species to higher altitudes. The notable tree species among these include: Betula utilis and Pinus wallichiana. Also, 67\% of the total respondents reported a change in this basin in terms of plant species composition in genus Pinus and Betula, which were rarely seen at higher altitude (Table 2). A similar change was reported in the Parbati Basin, where $60 \%$ of the respondents attributed this to: (i) road construction activities, (ii) increased fuelwood consumption with everincreasing human population, (iii) vegetation loss due to natural disasters - cloud bursts, flash floods, forest fires, etc., (iv) over-grazing and (v) decreased regeneration rate of trees in the forest area. Likewise, the non-glacier-fed regions like Imphal Basin showed shifting of plant species to higher altitudes and over the years this has been supported by about $12 \%$ of the total respondents (Annexure 1 and Table 2). A low diversity in the Changoubung forest due to repeated felling, and slash and burn (jhum) cultivation by the natives, and spreading of Tithonia diversifolia, Lantana camara and Mikania, etc. together have resulted in forest loss. The structure of the forest is further going to change when dependency on the forest resources increases as a result of low agricultural produce and extreme climatic events like cloud bursts and flash floods. 


\section{Impact on human beings}

The change in weather pattern also influenced human health, and altered range and seasonality of outbreak of vector-borne infections, e.g. malaria, dengue fever, etc. in all the study basins (Annexure 1). A study conducted on climate drivers on malaria transmission in Arunachal Pradesh $^{50}$, had revealed that climatic variables such as temperature and rainfall are the major influencing factors for the high rate of malaria transmission in East Siang district of the state.

\section{Capacity-building programme and social awareness}

Taking into consideration the complexities and adversaries within the forest ecosystem, adaptation as a result of climate change in recent years has become the key focus of scientific studies and policy guidelines. These aspects have now become important topics of discussion in the multi-lateral process ${ }^{51}$. Formulating adaptation strategies is a key factor that will not only make us conscious about the happenings in the real world, but also indicate future severity of climate change on different environmental sectors. These adaptations will require substantial involvement by farmers, governments, scientists and developmental organizations.

In view of knowing the views of the local communities for adaptation and resilience-building due to climate change, a series of four consultation meetings/capacitybuilding programmes of the local stakeholders in the IHR were organized. Some of the opinions were considered for formulating mitigation measures and adaptive strategies. The first consultative meeting was conducted on 22 and 23 November 2017 at Gagangir village in the Sindh Basin (Jammu \& Kashmir) wherein 74 participants took part. During the interactive session, the villagers raised issues like scarcity of drinking water supply, lack of tourism development, lack of road connectivity, upgradation of health and educational facilities, etc. They emphasized on deteriorating quality of drinking water which in a polluted form has been causing water-borne diseases because of an ongoing tunnel construction work. This tunnel would ensure all-weather connectivity between Srinagar and Kargil in the Ladakh region. The local people were of the view that the construction activity has deteriorated the surrounding fragile environment along with the headwater regions of the River Sindh ${ }^{52}$. Besides, people also mentioned that the valley has been witnessing extreme weather conditions such as torrential rainfall, cool summers, increasing hailstorms and cloudbursts. The disastrous effects of changing climate in the form of heavy rainfall was witnessed in Kashmir valley during 2014 , causing damage to lives and property ${ }^{53,54}$.

The second workshop was organized from 1 to 3 December 2017 with 25 participants at CSIR-North-East
Institute of Science and Technology, Lamphelpat-Imphal in the Imphal Basin in Manipur. Representatives from the Loktak Development Authority in Manipur raised issues related to the presence of phumdi (floating biomass) in the Loktak Lake causing excessive proliferation, thus deteriorating water quality, dwindling fishery resources and degradation of catchment due to siltation ${ }^{52}$. They also mentioned the problem of low diversity in the Changoubung forest due to repeated felling and burning for jhum cultivation by the local communities, heavy invasion by T. diversifolia, L. camara and Mikania, etc. Unpredictably, change in monsoon in terms of irregular distribution of rainfall has affected many livelihood sectors as well as vegetation in the region. The people mainly depend on local forest products and rainfed agricultural practices for their livelihood.

The third consultative meeting convened on 7 December 2017 at Old Ziro in the Ranganadi Basin with 28 participants and discussed the issues like scarcity of water for drinking and irrigation practices. Representatives were also of the view that water in their region is getting polluted day-by-day, and the main causes were attributed to deforestation, waterlogging, mining and non-plantation of native species. In addition, issues like shrinking agricultural land and landscape degradation were raised by the Ziro Biodiversity Management Committee (ZBMC), especially due to unchecked construction activities which have severely hampered tourist inflow in the valley ${ }^{52}$. The feedback received from the stakeholders was proper planning and management of newly constructed houses on a priority basis. At the same time, ritualistic activities need to be revived to maintain traditions.

The fourth but important consultative workshop was conducted on 27 December 2018 at Gram Panchayat Bershaini in the Parbati Basin with 45 participants. The president of the Panchayat (Pradhan) spoke in detail about the problem of solid waste management and its reuse options. Lack of awareness about solid waste management in the region was attributed as the biggest hindrance to the Swachh Bharat Mission. The head of the women's group (Mahila Mandal) raised issues related to scarcity of water for drinking and irrigation in the valley. The other issues mentioned were decrease in snowfall amount over the years. The changes in snowfall pattern in the region were linked with developmental activities like hydropower projects, constructions, etc. Skill development programmes especially for women were suggested such as bee-keeping, knitting and embroidery to enhance their livelihood options. In addition, microbial bio-composting from biodegradable solid waste was another probable livelihood option. The overuse of pesticides and loss in soil fertility were also raised from the angle of the farming community. Representatives from the hoteliers' association raised the problem of waste management and lack of infrastructural facilities with respect to tourism activities $^{52}$. 


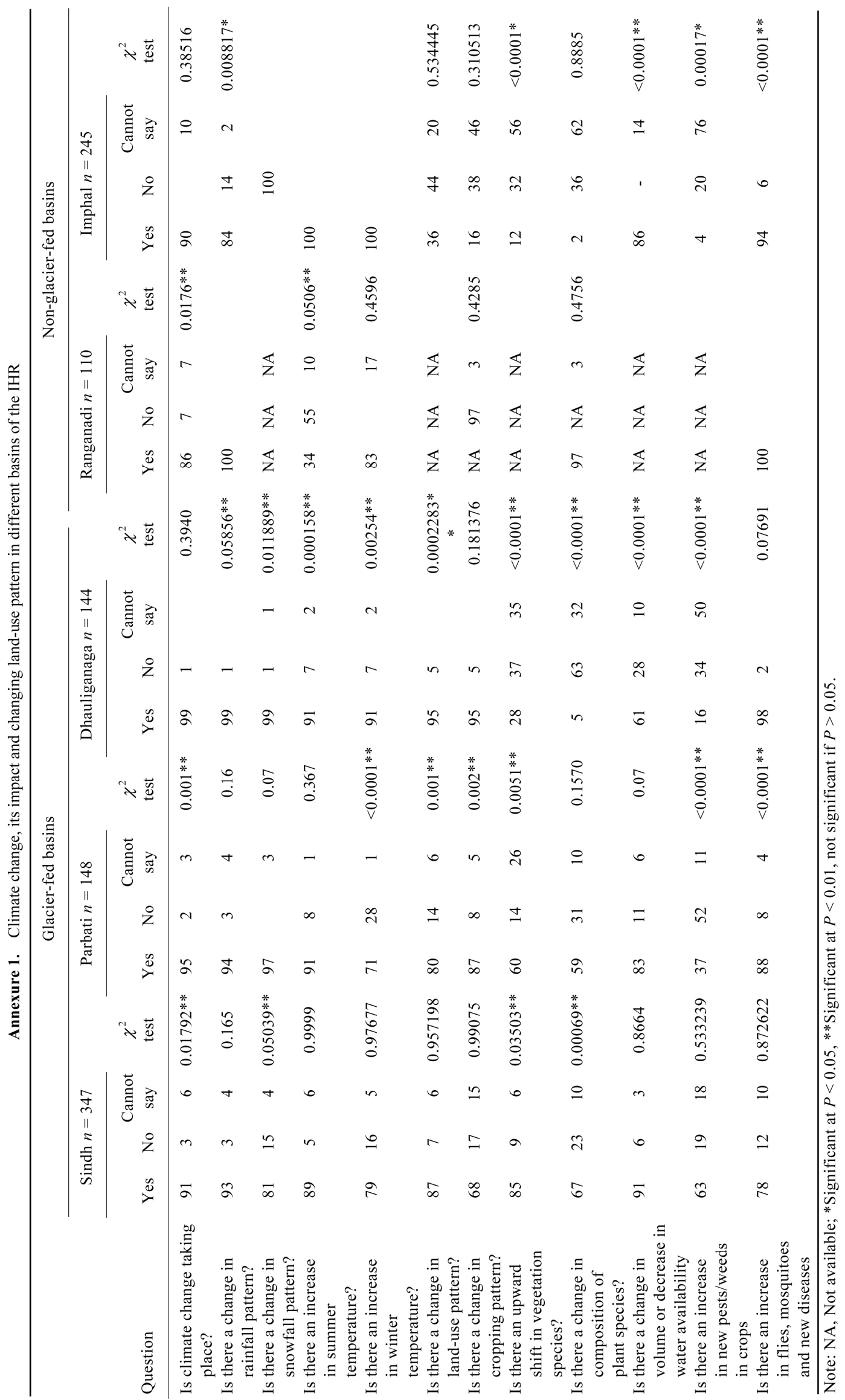


Response and adaptation measures to climate change by the community

The mountain ecosystem relies on seasonal rainfall and weather conditions which in the global context have been continuously changing. The impacts have been experienced over the last decades in the form of irregular rainfall, changes in its frequencies and volume, and rising temperatures leading to low agricultural crop production. Climate change has resulted in an increase in pests, diseases and invasive species (e.g. Eupatorium, Lantana, Parthenium), which directly affect crop productivity and food safety. During pandemic situations like COVID-19, self-reliant system with conservation and management practices of locally available resources or income sources may prove to be vital and sustainable. Further, rational use of locally available resources and confining diseases like COVID-19 at a place only would promote 'vocal for local' in the marginal areas and concerned communities in the Indian Himalayan Region. Table 2 describes the significant changes caused by climate change as experienced by the conventional societies in rural India. In order to cope with these changes, some of the communities have adapted measures based on their past knowledge and rich experience in glacier-fed and non-glacier-fed mountain regions (Table 3).

\section{Conclusion}

Synthesis from a perception based study highlights snowmelt contribution impacting river run-off. In addition, respondents were well aware of the ongoing phenomenon of climate change along with its future implications in their immediate region, as supported by analysis of seasonal climatic parameters (temperature and precipitation) for 35 years (1979-2014). The other natural resources likely to be impacted adversely were forests and change in land-use pattern. This is evident from a majority of the respondents who had supported the view that road construction, forest fires and over-grazing have multiplier negative impacts on the forest ecosystem and land-use pattern over the years. The implementation of mitigating measures and adaptation strategies is rarely taken into account at local, regional and national levels. In a nutshell, a number of consultation meetings/capacitybuilding workshops were conducted throughout the IHR. The problems raised by the villagers were more concerned with climate change and associated livelihood options. These communities are reacting to the changing scenario in a positive manner. They have begun some practices with reasonable adaptive measures. However, these are very few at the local level and need further expansion in states of the IHR. Therefore, a detailed study is required to plan future adaptation strategies that will improvize traditional practices with modern science and technology.
1. Singh, S. P., Singh, V. and Skutsch, M., Rapid warming in the Himalayas: ecosystem responses and development options. Climate Dev., 2010, 2, 221-232.

2. IPCC, Impacts, Adaptation, and Vulnerability; Part A: Global and Sectoral Aspects, Contribution of Working Group II to the Fifth Assessment Report, Cambridge University Press, Cambridge, UK, 2014.

3. Devkota, R. P., Climate change: trends and people's perception in Nepal. J. Environ. Prot., 2014, 5, 255-265.

4. Aggarwal, P. K., Impact of climate change on Indian agriculture. J. Plant Biol., 2003, 30, 189-198.

5. Dimri, A. P. and Dash, S. K., Winter time climatic trends in the western Himalayas. Climate Change, 2012, 111, 775-800.

6. Shekhar, M. S., Chand, H., Kumar, S., Srinivasan, K. and Ganju, A., Climate change studies in the western Himalaya. Ann. Glaciol., 2010, 51, 105-112.

7. Islam, Z. U., Rao, L. A. K., Zargar, A. H., Ahmad, S. and Khan, M. A., Temperature variability in Himalayas and threat to the glaciers in the region: a study aided by remote sensing and GIS. J. Environ. Res. Dev., 2008, 3, 496-505.

8. Bhutiyani, M. R., Kale, V. S. and Pawar, N. J., Climate change and the precipitation variations in the northwestern Himalaya: 1866-2006. Int. J. Climatol., 2010, 30, 535-548.

9. Shafiq, M. U. I., Islam, Z. U., Ahmad, W. S., Bhat, M. S. and Ahmed, P., Recent trends in precipitation regime of Kashmir valley, India. Disaster Adv., 2019, 12, 1-11.

10. Vogt, K. A. et al., Indigenous knowledge informing management of tropical forests: the link between rhythms in plant secondary chemistry and lunar cycles. Ambio, 2002, 31, 485-490.

11. Byg, A. and Salick, J., Local perspectives on a global phenomenon-climate change in eastern Tibetan villages. Global Environ. Change, 2009, 19, 156-166.

12. Chaudhary, P. and Bawa, K. S., Local perceptions of climate change validated by scientific evidence in the Himalayas. Biol. Lett., 2011, 7, 767-770.

13. Chaudhary, P., Rai, S., Wangdi, S., Mao, A., Rehman, N., Chhetri, S. and Bawa, K. S., Consistency of local perceptions of climate change in the Kangchenjunga Himalayas landscape. Curr. Sci., 2011, 101, 1-10.

14. Vedwan, N. and Rhoades, R. E., Climate change in the western Himalayas of India: a study of local perception and response. Climate Res., 2001, 19, 109-117.

15. Orlove, B., Roncoli, C., Kabugo, M. and Majugu, A., Indigenous climate knowledge in southern Uganda: the multiple components of a dynamic regional system. Climatic Change, 2010, 100, 243265.

16. Thomas, D. S. G., Twyman, C., Osbahr, H. and Hewitson, B., Adaptation to climate change and variability: farmer responses to intra-seasonal precipitation trends in South Africa. Climatic Change, 2007, 83, 301-322.

17. Chaturvedi, R. K., Ranjith, G. and Jayaraman, M., Impact of climate change on Indian forests: a dynamic vegetation modeling approach. Mitig. Adapt. Strat. Global Change, 2011, 16, 119-142.

18. Gopalakrishnan, R., Mathangi, J., Bala, G. and Ravindranath, N. H., Impact of climate change on Indian forests. Curr. Sci., 2011, 101, 348-355.

19. Sharma, E., Chettri, N., Tse-Ring, K., Shrestha, A. B., Jing, F., Mool, P. and Eriksson, M., Climate Change Impacts and Vulnerability in the Eastern Himalayas, International Centre for Integrated Mountain Development (ICIMOD), Kathmandu, 2009, pp. 1-29.

20. Patz, J. A., Campbell-Lendrum, D., Holloway, T. and Foley, J. A., Impact of regional climate change on human health. Nature, 2005, 438, 310-317.

21. Woodruff, R. E. and Guest, C. S., Predicting Ross River virus epidemics from regional weather data. Epidemiology, 2002, 13, 384393. 
22. Kuniyal, J. C., Mountain expeditions: minimizing the impact. Environ. Impact Assess. Rev., 2002, 22, 561-581.

23. Vishvakarma, S. C. R., Kuniyal, J. C. and Rao, K. S., Climate change and its impact on apple cropping in Kullu Valley, NorthWest Himalaya, India. In Seventh International Symposium on Temperate Zone Fruits in the Tropics and Subtropics, NauniSolan, 14-18 October 2003.

24. Uprety, D. C. and Reddy, V. R., Rising Atmospheric Carbon Dioxide and Crops, Indian Council of Agricultural Research, New Delhi, 2008.

25. Zahoor, U. L. and Khan, R. L. A., Climate change scenario in Kashmir Valley, India, based on seasonal and annual average temperature trends. Disaster Adv., 2013, 6, 30-40.

26. Thakur, N., Rishi, M., Sharma, D. A. and Keesari, T., Quality of water resources in Kullu Valley in Himachal Himalayas, India: perspective and prognosis. Appl. Water Sci., 2018, 8, 2-13.

27. Mishra, A., Changing climate of Uttarakhand, India. J. Geol. Geosci., 2014, 3, 163

28. Kabir, M. I., Rahman, M. B., Smith, W., Lusha, M. A. F., Azim, S. and Milton, A. H., Knowledge and perception about climate change and human health: findings from a baseline survey among vulnerable communities in Bangladesh. BMC Public Health, 2016, 16, 266.

29. Debela, N., Mohammed, C., Bridle, K., Corkrey, R. and McNeil, D., Perception of climate change and its impact by smallholders in pastoral/agropastoral systems of Borana, South Ethiopia. Springer Plus, 2015, 4, 236.

30. Koul, M. N., Bahuguna, I. M., Rajawat, A., Ali, A. S. and Koul, S. S., Glacier area change over past 50 years to stable phase in Drass Valley, Ladakh Himalaya (India). Am. J. Climate Change, 2016, 5, 88-102.

31. Kulkarni, A. V., Rathore, B. P., Mahajan, S. and Mathur, P., Alarming retreat of Parbati Glacier, Beas Basin, Himachal Pradesh. Curr. Sci., 2005, 88, 1844-1850.

32. Kuniyal, J. C. and Samant, S. S., Black carbon and other aerosols loading, and their impact on melting of the Parbati Glacier in the northwestern Himalaya, India. Report (25.09.2013 to 24.09.2016) submitted to DST (SERB Ref. No: EMR/SR/DGH-43/2012, SB/SO/04/09/2013), New Delhi, 2016, pp. 1-11.

33. Singh, D. K., Thakur, P. K., Naithani, B. P. and Kaushik, S., Temporal monitoring of glacier change in Dhauliganga basin, Kumaun Himalaya using geo-spatial techniques. Ann. Photogramm. Remote Sensing Spat. Inf. Sci., 2018, 4, 203-207.

34. Negi, V. S., Maikhuri, R. K., Pharswan, D., Thakur, S. and Dhyani, P. P., Climate change impact in the western Himalaya: people's perception and adaptive strategies. J. Mt. Sci., 2016, 14, 403-416.

35. Tripathi, A. and Singh, G. S., Perception, anticipation and responses of people to changing climate in the Gangetic plain of India. Curr. Sci., 2013, 105, 1673-1684.

36. Sharma, R. K. and Shrestha, D. G., Climate perceptions of local communities validated through scientific signals in Sikkim Himalaya, India. Environ. Monit. Assess, 2016, 188, 578.

37. Walther, G. R. et al., Ecological responses to recent climate change. Nature, 2002, 416, 389-395.

38. Rashid, I. et al., Projected climate change impacts on vegetation distribution over Kashmir Himalayas. Climate Change, 2015, 132, 601-613.
39. Thomas, C. D. et al., Extinction risk from climate change. Nature, 2014, 427, 145-148.

40. Gaira, K. S., Rawal, R. S., Rawat, B. and Bhatt, I. D., Impact of climate change on the flowering of Rhododendron arboreum in Central Himalaya, India. Curr. Sci., 2014, 106, 1735-1738.

41. Singh, S. P., Sharma, S. and Dhyani, P. P., Himalayan arc and treeline: distribution, climate change responses and ecosystem properties. Biodivers. Conserv., 2019, 28, 1997-2016.

42. Pandey, R., Kumar, P., Archie, K. M., Gupta, A. K., Joshi, P. K., Valente, D. and Petrosillo, I., Climate change adaptation in the Western-Himalayas: household level perspectives on impacts and barriers. Ecol. Indic., 2017, 84, 27-37.

43. Rautelala, P. and Karki, B., Impact of climate change on life and livelihood of indigenous people of higher Himalaya in Uttarakhand, India. Am. J. Environ. Prot., 2015, 3, 112-124.

44. Mukherji, A., Molden, D., Nepal, S., Rasul, G. and Wagnon, P., Himalayan waters at the crossroads: issues and challenges. Int. J. Water Resour. Dev., 2015, 31, 151-160.

45. Bajracharya, S. R., Mool, P. K. and Shrestha, B. R., Impact of climate change on Himalayan glaciers and glacial lakes: case studies on GLOF and associated hazards in Nepal and Bhutan, ICIMOD, Kathmandu, Nepal, 2007, pp. 1-117.

46. Nathani, A. K., Nainwal, H. C., Sati, K. K. and Prasad, C., Geomorphological evidences of retreat of the Gangotri glacier and its characteristics. Curr. Sci., 2001, 80, 87-94.

47. Prasad, V. H. and Roy, P. S., Estimation of snowmelt runoff in the Beas basin, India. Geocarto Int., 2005, 20, 41-47.

48. Zunlan, C., Jishan, W. U. and Xueyong, G., Debris flow dam formation in southeast Tibet. J. Mt. Sci., 2005, 2, 155-163.

49. Gupta, G. P., Sediment production status report on data collection and utilization. Soil Conserv. Digest, 1975, 3, 10-21.

50. Upadhyayula, S. M., Mutheneni, S. R., Chenna, S., Parasaram, V. and Kadiri, M. R., Climate drivers on malaria transmission in Arunachal Pradesh, India. PLoS ONE, 2015, 10, 1-17.

51. Ministry of Environment, National Adaptation Programme of Action (NAPA) to climate change, Kathmandu, Nepal, 2010, pp. $1-77$.

52. Kuniyal, J. C., Bhatt, S. U. and Singh, H. B., Anthropogenic impacts and their management options in different ecosystems of the Indian Himalayan Region. Curr. Sci., 2019, 117, 358-359.

53. Venugopal, R. and Yasir, S., The politics of natural disasters in protracted conflict: the 2014 flood in Kashmir. Oxf. Dev. Stud., 2017, 45, 424-442.

54. Bhatt, C. M. et al., Satellite-based assessment of the catastrophic Jhelum floods of September 2014, Jammu \& Kashmir, India. Geomat. Nat. Hazards Risk, 2017, 8, 309-327.

ACKNOWLEDGEMENTS. We thank the Director, Govind Ballabh Pant National Institute of Himalayan Environment, Kosi-Katarmal, Almora for providing the necessary facilities, and the Ministry of Environment, Forest and Climate Change, Government of India for financial support under the National Mission on Himalayan Studies to conduct this work.

doi: $10.18520 / \mathrm{cs} / \mathrm{v} 120 / \mathrm{i} 5 / 888-899$ 